PF 2019 (LXXIV): 163-170

\author{
JAN SOKOŁOWSKI \\ Instytut Filologii Słowiańskiej \\ Uniwersytet Wrocławski \\ ul. Pocztowa 9 \\ 53-313 Wrocław \\ +48713754557 \\ jansokol44@gmail.com
}

\title{
UWAGI O ZNACZENIU SŁOWIAŃSKICH PRZYMIOTNIKÓW MOTYWOWANYCH WYRAŻENIEM PRZYIMKOWYM BEZ DNA
}

Słowa kluczowe: derywat, języki słowiańskie, metafora, parafraza, przyimek, przymiotnik. Keywords: derivative, Slavic languages, metaphor, paraphrase, preposition, adjective.

\section{SOME REMARKS ON THE MEANING OF SLAVIC ADJECTIVES MOTIVATED BY THE SYNTACTIC PHRASE WITH THE PREPOSITION BEZ DNA}

\begin{abstract}
This paper is concerned with the semantic description of Slavic adjectives based on the syntactic phrase bez dna. The forms under discussion are analysed against other classes of adjectival derivatives with the negative preposition bez. The analysis of Slavic adjectives motivated by this expression leads to the conclusion that in comparative studies of morphological systems of Slavic languages, it is not only morphological meaning of derivatives, but also their metaphorical meaning that should be taken into consideration.
\end{abstract}

W systemach słowotwórczych współczesnych języków słowiańskich osobną klasę w obrębie derywatów motywowanych wyrażeniami syntaktycznymi stanowią formacje przymiotnikowe oparte na wyrażeniach syntaktycznych z przyimkiem negacji, typu pol. bezręki : bez ręki / rąk, bezdomny : bez domu, bezdrożny : bez drogi /dróg, bezwodny : bez wody, ros. безрукий: без руки/рук, бездомный : без дома, безводный : без водьи, бездорожный : без дорог, тас. бездомен : без дом, беспатен : без пат, безводен : без вода. 
Języki słowiańskie charakteryzują się zarówno podobieństwami, jak i różnicami w zakresie derywacji tego rodzaju przymiotników (Sokołowski 2000) ${ }^{1}$. Zasadniczo wspólny jest dla języków słowiańskich podstawowy inwentarz znaczeń kontekstowych derywatów przymiotnikowych opartych na wyrażeniach syntaktycznych z przyimkiem negacji, to znaczy znaczeń, jakie można przypisać tego typu przymiotnikom w połączeniu z określanymi przez nie rzeczownikami.

Dla licznych derywatów tego typu można zbudować parafrazę słowotwórczą typu

A (bez N) No - No, który nie ma $\mathrm{N}^{2}$,

np. bezoki mężczyzna ' mężczyzna, który nie ma oka / oczu'

$\mathrm{W}$ badanym materiale oprócz licznych formacji tworzących większe serie o znaczeniu 'relacja partytywna $\mathrm{z}$ negacją', 'relacja posesywna $\mathrm{z}$ negacją' czy też formacji komunikujących inne relacje $\mathrm{z}$ negacją, występują również przymiotniki mające znaczenia charakterystyczne tylko dla niewielkich serii derywatów lub pojedynczych formacji. Najczęściej są formacje oparte na metaforze ${ }^{3}$. Wśród przymiotników tego typu wyodrębnia się kilka grup. Niewielką, ale wyraźnie zarysowaną grupę, tworzą derywaty mające w podstawie słowotwórczej rzeczowniki o znaczeniu 'granica', takie jak: pol. brzeg (: bezbrzeżny), granica (: bezgraniczny), kraniec (: bezkrańcowy), kres (: bezkresny); ros. берег (: безбрежный), гранииа (: безграничныц ), край (: бескрайний), конеи (: бесконечный), предел (: беспредельный); тас. граница (: безграничен), крај (: бескраен), предел (: беспределен) wchodzące między sobą w relacje synonimiczne (Sokołowski 2005). Do tej niewielkiej grupy nawiązują pod względem znaczeniowym przymiotniki oparte na wyrażeniach syntaktycznych z przyimkiem bez i rzeczownikiem dno, który Wiesław Boryś w Słowniku prasłowiańskim definiuje w sposób

1 Problematyce tej poświęciłem szereg artykułów i obszerną monografię (Sokołowski 2000), w której pokazałem, że podstawowe podobieństwa i różnice dotyczą liczby i rodzaju formantów podstawowych wykorzystywanych w tworzeniu przymiotników motywowanych wyrażeniami syntaktycznymi z przyimkiem negacji, liczby derywatów z poszczególnymi formantami, oraz ich produktywności i frekwencji w poszczególnych językach słowiańskich. Między innymi języki słowiańskie mają bardzo podobny inwentarz rzeczowników wchodzących w skład wyrażeń motywujących. Rzeczowniki te charakteryzują się w znacznym stopniu podobnymi właściwościami semantycznymi i słowotwórczymi. Są wśród nich przede wszystkim liczne nazwy o znaczeniu nieprzedmiotowym oraz rzeczowniki nazywające części ciała człowieka i zwierzęcia, nazwy fragmentów środowiska naturalnego, nazwy przedmiotów wytworzonych przez człowieka i nazwy części takich przedmiotów, nazwy substancji i inne.

2 Symbole: A (bez N) -przymiotnik motywowany wyrażeniem syntaktycznym z przyimkiem negacji, bez - przyimek, N - rzeczownik wchodzący w skład wyrażenia motywującego, No rzeczownik określany. Wykorzystuję tu zapis, jaki stosuje K. Kallas w Gramatyce wspótczesnego języka polskiego (zob. Kallas 1984: 435).

3 Na temat derywatów o znaczeniu metaforycznym zob. Ermakova (1984), Nagórko (1987). 
następujący: 'najniższa warstwa, spód czegoś, dolna, spodnia ściana naczynia, spód zagłębienia, fundum; dolna wewnętrzna część czegoś wydrążonego, głębokiego' (SP V 162). W podobny sposób opisują podstawowe znaczenie rzeczownika dno słowniki współczesnych języków słowiańskich. Oprócz tego podstawowego znaczenia rzeczownika dno, odnoszącego się do charakterystyki wertykalnej elementów rzeczywistości pozatekstowej, słowniki języków południowosłowiańskich rejestrują też znaczenia horyzontalne tego rzeczownika. Wnikliwy opis tych znaczeń przynosi artykuł Janusza Siatkowskiego (Siatkowski 2001).

Słowiańskie przymiotniki z wyrażeniem $\mathrm{z}$ bez dna w podstawie słowotwórczej fundowane są na przedstawionym wyżej znaczeniu podstawowym rzeczownika dno. W większości języków słowiańskich u przymiotników tych słowniki wyodrębniają więcej niż jedno znaczenie. Chociaż w każdym z języków słowiańskich zawsze możliwe jest „prototypowe” dla tej klasy derywatów znaczenie 'relacja partytywna z negacjąa, znaczenie to wyodrębniają wielkie słowniki akademickie tylko niektórych języków słowiańskich: czeskiego, rosyjskiego, ukraińskiego i bułgarskiego. Znaczenie to można opisać za pomocą przytoczonej wyżej parafrazy A (bez N) No - No, który nie ma N, np.

cz. bezedný, řidč. bezdný 1 . 'nemající dno': b-á nádoba (SSJČ);

ros. бездонный 1. 'без дна' (SSRLJa);

ukr. бездонний 1. 'який не має дна; без дна': Дощ лив несамовито. Здавалося, десь угорі відкрилася глибока бездонна дірка і звідти без упину хлюпали бурхливі холодні потоки. (Донченко II 1956: 50) (SUM);

bg. бездънен 1. рядко 'който е без дъно'. Дъщерите на Даная се изскубват од напразните усилия да пълнят своя бездънен сад. (Бл. Димитрова. ОтО, 8. Бездънна делва (RBE).

Przymiotnik bezdenny w znaczeniu 'niemający dna, pozbawiony dna' odnotowuje również SJPDor, opatrując je cytatem z Pana Tadeusza:

A z góry garściami spada blask miesiąca. Myślałbyś, że u stawu siedzi Świtezianka, jedną ręką zdrój leje z bezdennego dzbanka, a drugą ręką w wodę dla zabawki miota brane z fartuszka garście zaklętego złota. Mick.Tad. 230.

Pozostałe słowniki współczesnego języka polskiego, na przykład słownik pod redakcją Mieczysława Szymczaka czy internetowy Wielki słownik języka polskiego, znaczenia tego nie wyodrębniają.

Obydwa słowniki odnotowują natomiast u przymiotnika bezdenny dwa znaczenia oparte na metaforze, które SJPSzym definiuje w sposób następujący:

pol. bezdenny 1. 'niezmiernie głęboki; przepaścisty': Bezdenna studnia. Bezdenne lochy, przepaście. Bezdenna kieszeń; 
2. 'ogromny, mający bardzo duże nasilenie; zwykle o czymś ocenianym ujemnie lub przykrym)': Bezdenni głupcy. Bezdenna głupota. Bezdenna pustka, rozpacz. Bezdenny smutek.

Podobnie opisuje znaczenia przymiotnika bezdenny Wielki słownik języka polskiego.

SJPDor, który również wyodrębnia te znaczenia, kwalifikuje je jako przenośne wobec znaczenia podstawowego ('niemający dna, pozbawiony dna').

Zgodnie z konwencją przyjętą w GWJP dla pierwszego z przytoczonych znaczeń ('niezmiernie głęboki; przepaścisty') można zaproponować ogólną parafrazę:

A (bez N) No - No, który wydaje się być bez N,

np. pol. Bezdenna przepaść 'przepaść, która wydaje się być bez dna'.

Przymiotniki, dla których można skonstruować taką parafrazę, definiowane są w słownikach języków słowiańskich zwykle za pomocą standardowych wyrażeń typu 'bardzo głęboki', 'jakby bez dna'.

Jak wynika $z$ danych słownikowych, słowiańskie przymiotniki oparte na wyrażeniu syntaktycznym bez dna, przybierają to znaczenie regularnie, niezależnie od tego, czy dany derywat przymiotnikowy komunikuje relację partytywną z negacją, czy też nie. W ten właśnie lub podobny sposób definiowane są na ogół w słownikach pozostałych języków słowiańskich:

pol. bezdenny 1. 'niezmiernie głęboki; przepaścisty' : Bezdenna studnia. Bezdenne lochy, przepaście. Bezdenna kieszeń (SJPSzym)

cz. bezedný, řidč. bezdný 1. 'jsoucí jako bez dna, velmi hluboký: b. oceán; b-á propast; b. močál (SSJČ);

słc. bezodný, bezdný 1. 'ktorý má vel'kú híbku, vyzerá ako bez dna’; syn. hlboký: bezdný oceán; bezodná priepast', studňa; bezdné močariská; Tam, kde stával Kostol svätej Alžbety, zívala bezdná a dymiaca jama (R. Jašík) (SSSJ);

ros. бездонный 2. 'чрезвычайно глубокий, как бы не имеющий дна' : Бездонная пропасть. Река кажется бездонным омутом, со всех сторон окруженным горами, высокими до неба и одетыми густым покровом тумана (М. Горький, На плоTax) (SRJa);

4 SJPDor egzemplifikuje to znaczenie w sposób następujący: bezdenny przen. a) „Wyjął (...) ze swych bezdennych kieszeni małą słuchawkę” (Brzech. Kleks, 27). „Dziś w zamku zostały zaledwie ślady okopów i wałów, zmurszała baszta (...) studnia bezdenna, wyschła, kurhan, pod który złożono obrońców” (Rodz. Dew. 40). „Bezdennych oceanów wodne bezgranicza, choć ich człowiek nie pije, do cudów zalicza” (Lem. Czyn 195). „A z głębin lochów, z bezdennych nor, z zionących stęchlizną grobów wychodziły nieskończone szeregi skazańców” (Reym. Now. IV, 23). „Od takiego długiego trzymania mię nad bezdenną przepaścią nie dziw, że głowa moja poczyna się zawracać” (Tremb. Listy 1, 246). 
ukr. бездоний 2. перен. 'дуже глибокий': Кругом вода, кругом киплять та піняться високі хвилі, чорніють бездонні кручі. (Мирний, I, 1954: 232) (SUM).

brus. бяздонны 'непамерна глыбоки' : Так загуста паыспана месацаў У бяздонную прорву вод, Што не пройдзе ніяк, не памесціицца Сярод гэтых вод параход (Панчанка) (TSBM);

serb. бѐздан ${ }^{2}$-а, -о 1. 'који је без дна, врло дубок’ - Сурва се .. . зине преда мном простор бездане празнине. (Гор.) (RMat);

chrw. bèzdan' 'koji je bez dna, neizmjerno dubok' (RAn);

słń. brezdanji knjiż. 'ki je brez dna, zelo globok': brezdanji prepad; brezdanja globina; okrog in okrog brezdanja voda.(SSKJ);

bg. bездънен 2 'който е многу дълбок, на които не може да се види дъното': Просто не можеше да се нагледа на високите планински върхове, които се губеха нагоре в ясното небо, или на бездъните пропасти, по чието дъно боботеха буйни балкански потоци. (М. Марчевски, ТC, 11) (RBE).

Chociaż słowniki języka macedońskiego (RMJ, TRMJ) nie notują przymiotnika opartego na wyrażeniu без $\partial н a$, to jest on jednak możliwy. Na występowanie przymiotnika бездонен w poezji macedońskiego poety Gane Todorowskiego (1929-2010) zwróciła mi uwagę Slavica Veleva, autorka monografii poświęconej kreatywności słowotwórczej tego poety (Велева 2004: 109).

Przymiotniki słowiańskie mające znaczenie omawianego typu określają rzeczowniki nazywające różne przedmioty materialne. Wyrazami określanymi przez przymiotniki słowiańskie oparte na wyrażeniach syntaktycznym z przyimkiem bez i rzeczownikiem dno są najczęściej takie rzeczowniki, jak: ocean, morze, rzeka, wody, głębia, topiel, toń, grzęzawisko; przepaść, wąwóz, jama, czeluść, otchłań. W grupie rzeczowników nazywających przedmioty materialne wykonane przez człowieka słowniki notują takie, jak np.: studnia, sadzawka, loch, kieszeń, sakiewka.

Oprócz opisanego wyżej znaczenia eksplikowanego w słownikach jako 'bardzo głęboki', 'jakby bez dna’, przymiotniki słowiańskie oparte na wyrażeniu bez dna przybierają też inne jeszcze znaczenia oparte na metaforze. W jednym $z$ takich znaczeń w większości języków słowiańskich przymiotniki motywowane tym wyrażeniem na ogół łączą się z rzeczownikami o znaczeniu nieprzedmiotowym, między innymi z rzeczownikami oznaczającymi różne stany emocjonalne, i informują o znacznej intensywności tych stanów. W ten sposób określane rzeczowniki otrzymują charakterystykę przestrzenną opartą na metaforze (Wierzbicka 1971), co zbliża je do opisanych już takich przymiotników, jak: pol. bezbrzeżny, bezgraniczny; cz. bezhraničný kniž., bezmezný; ros. безграничныц̆, бесконечный, беспредельный; bg. безграничен, mac. безграничен (Sokołowski 2005). 
pol. bezdenny 2. 'ogromny, mający bardzo duże nasilenie; zwykle o czymś ocenianym ujemnie lub przykrym)': Bezdenni głupcy. Bezdenna głupota. Bezdenna pustka, rozpacz. Bezdenny smutek. (SJPSzym)

cz. bezedný expr. 'nesmírně veliký; nesmírně dlouhý, dlouho trvající; nesmírný, neomezený, veliký, nekonečný, vleklý: b-á bída; b-é hoře; b-á dálka, prázdnota (SSJČ);

słc. bezodný, bezdný 2. expr. majúci vel'kú intenzitu, mieru, neohraničený rozsah, bezhraničný, nekonečný: bezodná fantázia, túžba; bezodné sklamanie, zúfalstvo; Prepadol sa kamsi do bezodnej prachovej búrky, čo zúrila naokol. (J. Puškáš); Aká je tu zábava? Iba bezodná nuda (V. Mináč) (SSSJ).

ukr. бездоний 2. перен. 'дуже сильний’ Вона всміхалася, одкрита і жива, В очах світилася любов її бездонна (Євген Фомін, Вибр., 1958: 177) (SUM);

srb. 2. бескрајан фиг. 'огроман, страшан' - Поквареност која нема мјере, бездана поквареност (Куш) (RMat);

słń. brezdanji ekspr. 'ki zelo presga navadno mero': brezdanji obup; brezdanja bolečina, žalost; $v$ očeh je žarelo brezdanje sovraštvo / pesn. brezdnja modrina, tema (SSKJ);

bg. бездънен 4. Прен. Книж. Обикн. за чувства, преживявания и под. 'много голям, изключително голям, силен; безкраен, безпределен' Прегръзщаше класовете и от бездънна милост ронеше сълзи върху запечената угар (К. Петканов, M3K 156) (RBE).

Chociaż przedstawione tu uwagi oparte są na stosunkowo skromnym materiale, to jednak uzasadniony jest wniosek, że w badaniach konfrontatywnych systemów słowotwórczych języków słowiańskich przedmiotem opisu mogą być nie tylko znaczenia prymarne derywatów, ale także ich znaczenia metaforyczne, które mogą być wspólne dla części lub nawet wszystkich języków słowiańskich.

\section{Bibliografia}

Kallas Krystyna, 1998, Słowotwórstwo przymiotników, [w:] Gramatyka współczesnego języka polskiego. Morfologia, red. Renata Grzegorczykowa, Roman Laskowski, Henryk Wróbel, Warszawa.

5 SJPDor definiuje znaczenie przymiotnika bezdenny w następujący sposób: 'ogromny, bezgraniczny, bezkresny’. Znaczenie to egzemplifikowane następującymi przykładami: „Despotyzm łączy się w nim z jakąś pożerającą złością wewnętrzną, odsuwającą wszelkie skrupuły, byle dogodzić bezdennej pysze i żądzy władzy” (Loren. Dwadz.169). „Cenzura dokazałaby nie lada sztuki, znalazłszy cośkolwiek w „Synu chmur”, który był bezdenną czczością” (Gomul. Ciury I, 68). „Pałał on [Lelewel] żądzą rozjaśnienia mroków, otaczających dziejowy pochód ludzkości, a wiedzę posiadał bezdenną” (Śliw. A. 72). „Nagle uczuł bezdenną pustkę w głowie i ocknął się przerażony (Prus. Dzieci 178). „Zagrała sonatę Beethowenowską, co się poczyna bezdenną rozpaczą i zwątpieniem dogorywającym (...)” (Krasz. Czarna, 272). 
Nagórko Alicja, 1987, Zagadnienia derywacji przymiotników, Warszawa.

Siatkowski Janusz, 2001, Znaczenia horyzontalne wyrażeń z leksemem dno w językach południowosłowiańskich, „Prace Filologiczne” 2001, t. 46, s. 547-551.

Sokołowski Jan, 2000, Słowiańskie derywaty imienne z przyimkiem negacji w podstawie słowotwórczej, „Acta Universitatis Wratislaviensis” No 2228, Slavica Wratislaviensia CX, Wrocław.

Sokołowski Jan, 2005, Ze studiów konfrontatywnych nad semantyką przymiotników w językach słowiańskich, [w:] Ogród nauk filologicznych. Księga jubileuszowa poświęcona Profesorowi Stanisławowi Kochmanowi, red. Mieczysław Balowski, Wojciech Chlebda, Opole.

Wierzbicka Anna, 1971, Kocha, lubi, szanuje. Medytacje semantyczne, Warszawa.

Велева Славица, 2004, Зборообразувањето во поезијата на Гане Тодоровски, Скопје. Ермакова Ольга П., 1984, Лексические значения производных слов в русском языке. Москва.

Сјатковски Јануш, 2001, Хоризинтални значења на изразите со лексемата дно во јужнословенските јазици, “Македонски јазик”, год. LI-LII, 2000-2001, Скопје.

\section{Słowniki}

RAn - Vladimir Anić, Rječnik hrvatskoga jezika, Zagreb 1991.

$\mathrm{RBE}$ - Речник на българския език, т. 1 (А-Б), ред. Кристалина Чолакова, София 1977. RMJ - Речник на македонскиот јазик со српскохрватски толкувања, ред. Блаже Конески, т. 1, Скопје 1961.

RMat - Речник српскохрватскога књижевног језика, књ. 1, Нови Сад-Загреб 1967. SJPDor - Słownik języka polskiego, red. Witold Doroszewski, t. I-XI, Warszawa 19581969.

SJPSzym - Słownik języka polskiego, red. Mieczysław Szymczak, t. I-III, Warszawa 1978-1981.

SP - Słownik prasłowiański, opr. Zespół Zakładu Słowianoznawstwa PAN, red. Franciszek Sławski, Wrocław 1974.

SRJa - Словарь русского языка в четырех томах, изд. 2-е исправленное и дополненное, Анастасия П. Евгеньева, т. 1-4, Москва 1981-1984.

SSJČ - Slovník spisovného jazyka českého, red. Bohuslav Havránek i in., zv. 1-4, Praha 1960-1971.

SSJ - Slovník slovenského jazyka, red. Štefan Peciar, sv. I, Bratislava 1959-1968.

SSKJ - Slovar slovenskega knjižnega jezika, t. 1-5, Ljubljana 1970-1991.

SSSJ - Slovník súčasného slovenského jazyka, red. Klára Buzássyová, Alexandra Jarošová, zv. 1, Bratislava 2006.

SUM - Словник української мови, ред. Іван К. Білодід, т. I, Київ 1970.

TRMJ - Толковен речник на македонскиот јазик, т. 1-6, главен ред. Кирил Конески, Скопје 2003-2014.

TSBM - Тлумачальны слоўнік беларускай мовы, т. 1-5, Мінск 1977-1984. 


\section{Streszczenie}

Przedmiotem artykułu jest charakterystyka semantyczna słowiańskich przymiotników opartych na wyrażeniu syntaktycznym bez dna. Badane formacje analizowane są na tle innych klas derywatów przymiotnikowych motywowanych wyrażeniami syntaktycznymi z negacyjnym przyimkiem bez. Analiza znaczenia słowiańskich przymiotników motywowanych tym wyrażeniem pozwala na stwierdzenie, że w badaniach konfrontatywnych systemów słowotwórczych języków słowiańskich przedmiotem opisu powinny być nie tylko znaczenia słowotwórcze derywatów, ale również ich znaczenia metaforyczne. 